\title{
Disinfection Water Wells and Sterilization
}

\author{
Mehaysen Ahmed Mahasneh \\ Al-Huson University Collage, Al-Balq'a Applied University, Irbid, Jordan \\ Email: Mahsneh2008@hotmail.com
}

Received 4 February 2016; accepted 11 April 2016; published 15 April 2016

Copyright (C) 2016 by author and Scientific Research Publishing Inc.

This work is licensed under the Creative Commons Attribution International License (CC BY). http://creativecommons.org/licenses/by/4.0/

c) (†) Open Access

\begin{abstract}
Disinfection is an important step in ensuring that water is safe to drink. Well disinfection is used to inactivate or control bacteria populations in a well and the distribution system. Disinfection is the inactivation or destruction of pathogenic organisms through the disruption of the organisms' normal life processes. The objective of this work is to clean and/or disinfect entire borehole to prepare wells for pump installation. The last water sample was collected after the well disinfection on that time. The results of water chemical analysis are presented in Tables $2-4$, and there was nothing found against the specification requirements. After a reaction time of approximately $12 \mathrm{~h}$, the well was cleaned from the sterilization solution by airlifting until chlorine concentration in the water reached $0 \mathrm{mg} / \mathrm{l}$. Then through analyzing the test for samples of water after disinfection and sterilization the wells showed the Iron Bacteria were not seen and the Bacteria Species/Anaerobic Bacteria were absent.
\end{abstract}

\section{Keywords}

Well Disinfection, Chlorination, Turbidity, Anaerobic Bacteria, Sterilization

\section{Introduction}

The source of the water determines the characteristics of the water. Water sources, in order of decreasing quality, include springs, boreholes, sealed wells, hand-dug wells, streams, rivers, and lakes. Boreholes are wells drilled with a drilling rig, and like springs, tap groundwater sources that have been filtered through layers of soil and rock and are isolated from the surface. These sources may contain unpleasant color, odor or minerals but are generally free from pathogen contamination and, therefore, will not require disinfection. Sealed wells are shallow wells that have been sealed with cement around a pump to prevent contamination. However, contamination is possible, and sealed wells are often treated with chlorine. Hand-dug wells are typically contaminated. Wells become contaminated from contamination water entering the well from above, especially during flooding. Improper drainage (sloping in toward the well) also promotes well contamination. 
In a paper published in 1894, Moritz Traube formally proposed the addition of chlorined of lime (calcium hypochlorite) to water to render it "germ-Free". Two other investigators confirmed Traubes findings and published their papers in 1895 [1]. Chlorine in the form of a mixture of chloride of lime and chloride of iron were added to a highly colored water supply over the period of 1902 to 1921 [2] [3].

In the USA, the first use of chlorine for continuous disinfection of a drinking water supply took place in 1908 at Boonton Reservoir (on the Rock way River), which served as the supply for Jersey City, New Jersey [4].

Chlorine gas was first used on a continuing basis to disinfect the water supply at the Belmont filter plant, Philadelphia, Pennsylvania in 1913. Darnell's work and the technological innovations by Dr. George Ornstein and the Wallace \& Tiernan Company became the basis for present systems of chlorination of municipal water supplies. By 1941, disinfection of U.S. drinking water by chlorine gas had largely replaced the use of chloride of lime [3] [5]. When chlorine is added to water, it reacts to form PH dependent equilibrium mixture of chlorine, hypochlorous acid and hydrochloride acid [6]

$$
\mathrm{CL}_{2}+\mathrm{H}_{2} \mathrm{O} \longrightarrow \mathrm{HOCL}+\mathrm{HCL}
$$

Depending on the $\mathrm{PH}$, hypochlorous acid partly dissociates to hydrogen and hypochlorite ions:

$$
\mathrm{HOCL} \longrightarrow \mathrm{H}^{+}+\mathrm{CLO}^{-}
$$

In acid solution, the major species are $\mathrm{CL}_{2}$ and $\mathrm{HOCL}$ while in alkaline solution effectively only $\mathrm{CLO}^{-}$is present. Very small concentrations of $\mathrm{CLO}_{2}^{-}, \mathrm{CLO}_{3}^{-}, \mathrm{CLO}_{4}^{-}$, are also found [7].

Natural ground water from all but very shallow aquifers is considered free from pathogenic (disease causing) bacteria and viruses (Bouwer, 1984) [8]. As such, ground water obtained from properly designed and constructed water wells is generally free of diseases causing bacteria, and continuous disinfection is unnecessary (Roscoe Moss company, 1990) [9]. However, disinfection of a new or repaired water supply system is needed to remove contaminants introduced during the construction or repair process (Driscoll, 1986). Existing water supplies require disinfection when routine maintenance of the system takes place, or when the results of water samples show the presence of coliform bacteria (Driscoll, 1986) [10].

Disinfection is the inactivation or destruction of pathogenic organisms through the disruption of the organisms' normal life processes (Connell, 1996) [11]. Disinfection does not mean sterilization result of the effective disinfection is production of potable or drinkable water.

The objective of this study includes the proper water supply system preparation, including the sanitary completion of water well, the cleaning of existing wells, and the proper development of new wells, through flushing of the water supply, by treatment with a properly prepared chlorine solution, collection and analysis of water samples.

\section{Sanitary Drilling Practices}

The introduction of microbial contaminants, into newly constructed or repaired wells can be minimized by practicing good general sanitation during storage, transport, handling and installation of well components.

Proper sanitation refers to cleanliness and taking precaution to prevent disease by not introducing bacteria and other contaminants while installing or repairing a water supply system. When the drilling contractor takes precautions to prevent the unnecessary introduction of contaminants into the well, the task of disinfecting the well becomes much easier.

The storage and transportation of well components and drilling supplies should be in good sanitation by the contractor starts at the shop and is important during the trip to the drilling site. The organization and storage of materials and equipment will benefit the contractor during the installation and final disinfection of the completed water supply system [12].

\section{Well Evaluation}

Prior to install the permanent pump CCTV survey was done to check the borehole conditions. The first CCTV survey (as final check) was carried out after the well A was completed from the depth of $144 \mathrm{~m}$ to the end of PHC, some areas were seen with minor biofouling, including the stripped pattern as shown (Figure 1). Through the final CCTV and bacteriological laboratory results on the collected water samples it was confirmed that in the well B, ongoing processes from biofouling and corrosion may not affect the future productivity or integrity of the well. 

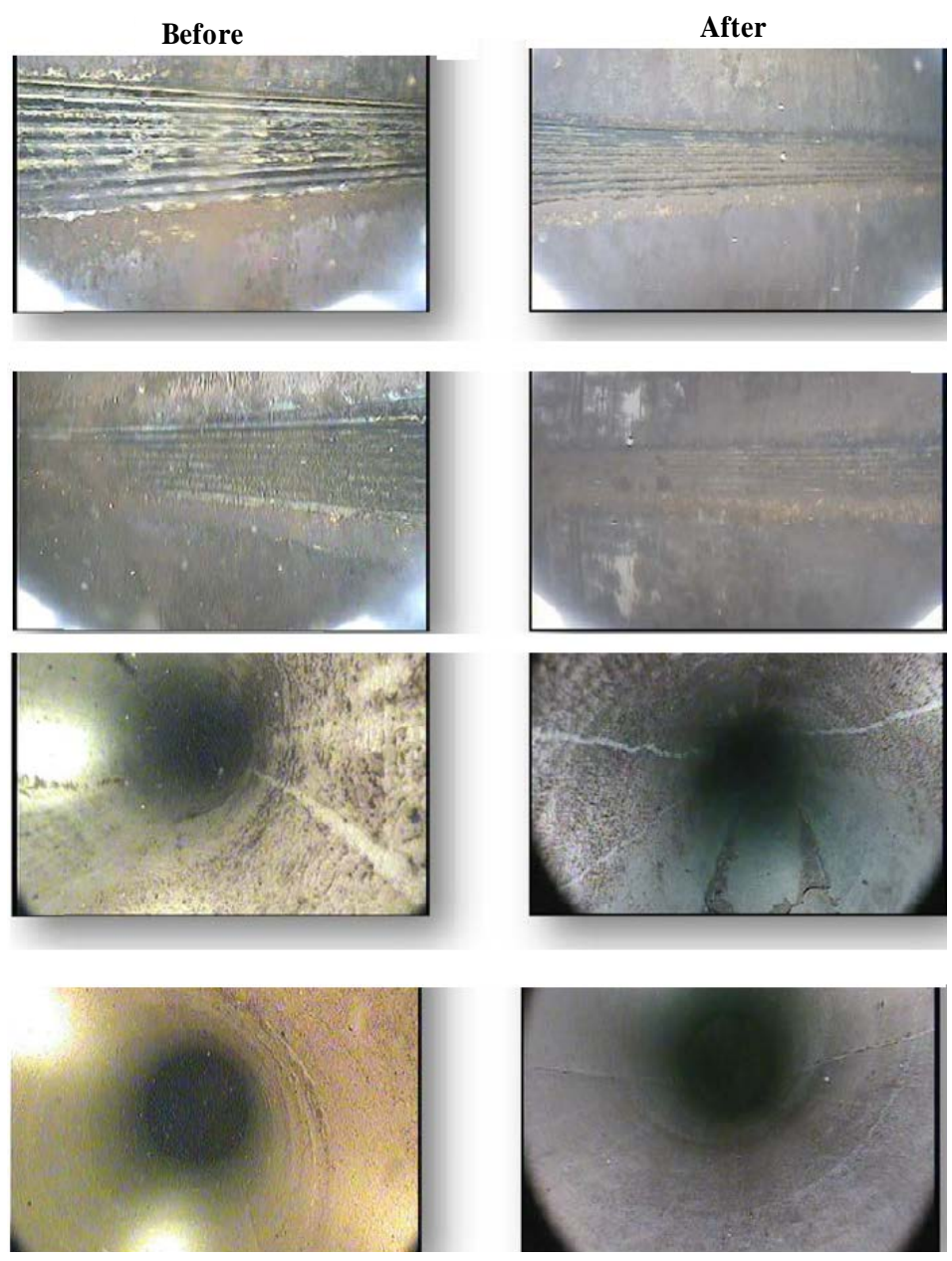

Figure 1. CCTV comparison well cleaning before and after disinfection.

\section{Factors Influencing Chlorination}

1) Constituents of water-Natural waters represent complex solutions of many substances, most of which can be ignored, but some of which influence chlorination as follows:

a) Suspended solids: may shield bacteria from the faction of chlorine.

b) Organic Matter: reacts with chlorine and removes it from the water so that it no longer has disinfecting properties.

c) Ammonia-reacts with chlorine to form a chlorine compound (chloramines) having much lower disinfecting qualities than chlorine itself.

d) Nitrates, Manganese and Iron-react with and remove chlorine and may produce a false color when testing water for chlorine content.

2) Temperature-The temperature of water marked by affects the disinfecting action of residual available chlorine. Other things being equal, chlorination is most effective with high water temperatures. At lower temperatures, bacterial kill tends to be slower and higher residual concentrations are needed. The effect of low temperatures is greater with combined available chlorine than with free available chlorine, 1890, 1978.

3) $\mathrm{PH}-\mathrm{The} \mathrm{PH}$ of the water affects the disinfecting action of chlorine, particularly combined available chlorine residual that the disinfecting action of chlorine is more efficient at lower $\mathrm{PH}$ values of the normal $\mathrm{PH}$ range of water supplies.

4) Time-concentration, these two mutually related factors take into consideration the period of reaction time available for disinfection and the quantity and Kind of chlorine residual. A greater concentration acting over a longer period of time must be provided, on the other hand, if free available chlorine residual, an active disinfec- 
tant, is to be maintained the reaction period can be correspondingly less. The minimum contact time should be 30 minute and preferably with an undesirable concentration of residual chlorine.

e) Chlorine Dosage

The amount of chlorine needed to accomplish disinfection or other treatment objectives, depends on the chlorine demand of the water, the amount and kind of chlorine residual desired, the time of contact of the chlorine with the water and the volume of flow to be treated [13]. Chlorine demand depends on the kind and concentration of chlorine reactive materials in the water, temperature and contact time. The chlorine required is that amount necessary to affect a specific chlorine residual at the end of a fixed contact period, the combination of which, under well defined operating conditions (PH and temperature) is demonstrably effective in accomplishing disinfection as well as providing the desired free chlorine residual at the end of specific contact time. The required dosage (rate of chlorine application per unit of water flow) to disinfect water supplies not subject to significant contamination normally should not exceed $2 \mathrm{mg} / \mathrm{L}$. The required chlorine feed rate is obtained as follows:

Chlorine feed rate $=$ chlorine Dosage $(\mathrm{mg} / \mathrm{L}) *$ flow $(8.34) \mathrm{lb} / \mathrm{gal}$

Pounds per day Percentage of free chlorine available

$1 \mathrm{mg} / \mathrm{L}=8.34 \mathrm{lb}$ of free chlorine per million gallons

$1 \mathrm{mg} / \mathrm{L}=\mathrm{LPPM}$.

\section{Dosage and Calculations}

1) Stock solution: the quantity of hypochlorite solution prepared at one time for the stock solution should be sufficient to last for about two weeks. A common strength for the solution to be fed into the system is $1 \%$ available chlorine; this means that every gallon, or $8.34 \mathrm{lb}$., will contain $0.0834 \mathrm{lb}$., or $1.34 \mathrm{oz}$., of active chlorine. If $70 \%$ hypochlorite is used, each gallon of $1 \%$ solution will contain $1.34 / 0.7$, or $1.92 \mathrm{oz}$. of material. The weights in ounces of hypochlorite required to chlorinate various quantities of water from a $1 \mathrm{mg} / \mathrm{L}$ to a $200 \mathrm{mg} / \mathrm{L}$ dosage. The gallons of water needed to prepare a $1 \%$ solution using this quantity of hypochlorite, is found by divided the weight in ounces by 1.92 in the case of $70 \%$ hypochlorite.

2) Feed Rate: The rate at which stock solution is fed into the system should be based on the actual pump age, in gallon per minutes, and not on the average over-all 24 hour consumption. The volume of $1 \%$ chlorine solution needed per minute to furnish a $1 \mathrm{mg} / \mathrm{L}$ chlorine dosage when injected into a pipe line following $1000 \mathrm{gpm}$ is:

$\operatorname{Dosage}(\mathrm{mg} / \mathrm{L})=($ Flow $(\mathrm{Mg} / \mathrm{pm})) /($ percent of chlorine $)=$ feed rate $(\mathrm{gpm})$ equation (2)

$1 \times 0.001 / 0.01=0.1 \mathrm{gpm}$

Hypochlorite solution $(\mathrm{ml} / \mathrm{min})=0.3785$ dosage $\mathrm{mg} / \mathrm{L} \times$ flow $(\mathrm{gpm})$ equation (3)

\section{Well Disinfection}

After constructing or repairing a well or pump, the entire well and pumping system must be disinfected in order to kill harmful microorganisms (germs and bacteria) that may be on the well casing, gravel, soil, rising main, pumping rod or in the water from the digging operation.

A life water well was just drilled to a depth of 500 to 550 meters (1640.5 to 1804.5 fetes) [14]. The pumping rod and riser pipe have been installed and, prior to sealing the well, it should be disinfected. The water level in the well is 126.92 meters (416.42 feet) below the ground level, the well completed as open hole. What are the steps that should be taken on disinfect this well? How much calculation hypochlorite should be added?

Calculation of volume for disinfection \& sterilization

1-Determine the volume for water in the well.

Area of circle $=\Pi * \mathrm{r}^{2}$

r: Radius of $185 / 8$ (casing diameter $185 / 8$ )

a) $\mathrm{r}=185 / 8=47.30 \mathrm{~cm}=0.473 \mathrm{~m}$

Area $=3.14 * 0.473 * 0.473=0.702 \mathrm{~m}^{2}$

Height of water column $=$ well depth-depth to water $($ water level $)=550-126.92=369.38 \mathrm{~m}$

Height of water column $=369.38 \mathrm{~m}$

b) Volume $=$ Area $*$ Height $=0.702 \mathrm{~m}^{2} * 369.38 \mathrm{~m}=259.30 \mathrm{~m}^{3}$

Volume $=259.30 * 1000 \mathrm{l} / \mathrm{m}^{3}=259304.7 \mathrm{~L}$

water level $126.92 \mathrm{~m}$, open hole $17^{1 / 2}$ OD length $169.85 \mathrm{~m}$ T.D (m) 550 casing $18^{5 / 8}$ OD length $169.85 \mathrm{~m}$ 
1-calculations of volume for disinfection \& sterilization

A-volume inside $18^{5 / 8}$ OD PHC section Height of water $315-126.92=169.85 \mathrm{~m}, 169.85 * 0.159 \mathrm{~m}^{3} / \mathrm{m}=$ $27.117 \mathrm{~m}^{3}$

B-volume inside $10^{3 / 4}$ OD screen section $176.08 * 0.05851 \mathrm{~m}^{3} / \mathrm{m}=10.302 \mathrm{~m}^{3}$.

C-volume inside $103 / 4$ casing $63.32 * 0.05025 \mathrm{~m}^{3} / \mathrm{m}=3.182 \mathrm{~m}^{3}$

D-volume inside gravel pack (GP volume * porosity $30 \%$ ) $=31.8 \mathrm{~m}^{3} * 30 \%=9.540 \mathrm{~m}^{3}$

Total volume $=50.141 \mathrm{~m}^{3}$

2-Quantity of calcium Hypochlorite for free chlorine, dosage at $50 \mathrm{ppm}$ in casing and screen sections.

Total volume $\times 0.08 \mathrm{~kg} / \mathrm{m}^{3}=50.141 * 0.080=4.011 \mathrm{~kg}$

-Quantity of calcium hypochlorite for free chlorine dosage at $100 \mathrm{ppm}$ in casing sections.

Quantity = total volume *0.160 kg/m $\mathrm{m}^{3}=69.236 * 0.160 \mathrm{~kg} / \mathrm{m}^{3}=1107 \mathrm{~kg}$

Program 1:

Mixed water $56 \mathrm{~m}^{3}$, Calcium Hypochlorite $=4.48 \mathrm{~kg}$

Pumping Steps \#7 by $8 \mathrm{~m}^{3}$ of solution

Program 2:

Calcium Hypochlorite tablet dosage at 50 ppm:

Sterilization Test information-Used: Mixed water 58 calcium Hypochlorite 4.7 kg Start Pumping as following:

$1^{\text {st }}$ step $8 \mathrm{~m}^{3}$ at depth $533 \mathrm{~m}$

$2^{\text {nd }}$ step $8 \mathrm{~m}^{3}$ at depth $467 \mathrm{~m}$

$3^{\text {ed }}$ step $8 \mathrm{~m}^{3}$ at depth $425 \mathrm{~m}$

$4^{\text {th }}$ step $8 \mathrm{~m}^{3}$ at depth $339 \mathrm{~m}$

$5^{\text {th }}$ step $8 \mathrm{~m}^{3}$ at depth $317 \mathrm{~m}$

$6^{\text {th }}$ step $8 \mathrm{~m}^{3}$ at depth $271 \mathrm{~m}$

$7^{\text {th }}$ step $8 \mathrm{~m}^{3}$ at $209 \mathrm{~m}$

$8^{\text {th }}$ step $0 \mathrm{~m}^{3}$

Dead volume $2 \mathrm{~m}^{3}$

Calcium Hypochlorite comes in strengths ranging from 30 - 75 percent available chlorine 70 percent most common). Chlorine is a very reactive substance. When added to a well, it first combines with inorganic compounds (hydrogen sulphide, ferrous iron, manganese) there no disinfection in this stage. After these compounds have been reduced, remaining chlorine then reacts with organic matter (algae, phenols and slime growth). After the demand exerted by inorganic and organic compounds has been met, chlorine will combine with nitrogen compounds (Primarily ammonia) to form chloramines. This combined chlorine form results in long lasting disinfection.

During the contact time the chlorine residual should be maintained in the water supply system for 4 to 12 hours (Coombs, 2001) [15]. For increased contact time to be most effective, the $\mathrm{pH}$ of the chlorine solution in the well must be maintained between 6 and 7 to keep the chlorine in anon oxidative state (hypochlorous acid). If $\mathrm{pH}$ control is not going to be used during periods of increased contact time, use concentrations of chlorine 50 ppm or less (Schnieders, 1998, 2001) [16] [17].

Table 1 shows the sterilization of the well was carried out by injecting $100 \mathrm{ppm}$ Ca-Hypochlorite solution through the drill pipes. For this purpose $4.5 \mathrm{~kg}$ of Ca-Hypochlorite were mixed with $56 \mathrm{~m}^{3}$ of water and pumped through the drill pipes and the washing tool at eight different depths between $209 \mathrm{~m}$ bRP and $533 \mathrm{~m}$ bRP. At each depth, $8 \mathrm{~m}^{3}$ of solution was injected. After a reaction time of approximately $12 \mathrm{hr}$, it was confirmed with to Coombs, 2001 for increased contact time to be most effective, the well was cleaned from the sterilization solution by airlifting until chlorine concentration in the water reached $0 \mathrm{mg} / \mathrm{l}$. produce minimal chlorine taste/odor and control organic growths.

From on site measurements, however, chlorine has also found application for a variety of other water treatment objectives, such as, the control of nuisance organisms, oxidation of taste and odor compounds, oxidation of Iron and manganese, color, removal, and as a general treatment aid to filtration and sedimentation processes (Connell, 1996; Williams and Culp, 1986) [11] [18]. Proper development of the well facilitates removal of these materials, which increase the success rate the disinfection stage well water must be free of turbidity. Suspended particles in turbid water interfere with the chlorines efforts to make contact with a kill microorganisms (Lechevallier et al.) [19]. 
Table 1. Control chlorine analysis $(\mathrm{mg} / \mathrm{L} \mathrm{CL} 2)$.

\begin{tabular}{cccc}
\hline Analysis & Concentration mg/l & Time min & event \\
\hline 1 & 50.00 & $7-8$ & After start of air lift pumping \\
2 & 4.00 & $8-10$ & 120 min after start of air lift pumping \\
3 & 0.0 & $10-15$ & 300 min after start of air lift pumping \\
4 & 0.0 & $15-19$ & 240 min \\
& & & 12 hours during final Inspection \\
\hline
\end{tabular}

\section{Water Quality}

\section{Field Hydrochemistry and Water Sampling}

Water samples for chemical analyses were collected from the sampling tap during SRPT. The samples were taken 1 hour and 23 hours after the start of the test. Both samples were analyzed for physical parameters, major and minor ions. The second sample was, in addition, analyzed for bacteriological parameters. The two samples were received by the Laboratories and Water Quality Sector, Water Authority of Jordan, Amman. On- ${ }^{-}$ite measurements are presented in Table 2.

A third sample was collected after well sterilization and analyzed (Table 3, Table 4).

\section{Results Interpretation}

Laboratory Analyses of the Jordanian Drinking Water Standards are based on standards from the World Health Organization. As the Jordanian standards do not mention threshold values for certain parameters, in such a case the values stipulated in the EU guidelines from 1998 are used as reference [11].

The results of the laboratory analyses of the three samples taken are presented in Table 2, which shows a comparison of the laboratory results with the respective threshold values of aforementioned standards:

The total dissolved solids $320 \mathrm{mg} / \mathrm{l}$ are low and typical of low mineralized groundwater from sandstone aquifer. These values correspond to the electrical conductivity, with values between 370 and $339 \mu \mathrm{S} / \mathrm{cm}$. The threshold value for manganese $(0.1 \mathrm{mg} / \mathrm{l})$ is exceeded on both samples, with concentrations of 0.27 and $(0.48 \mathrm{mg} / \mathrm{l})$ aerobic.

The bacteriological analyses after $23 \mathrm{hr}$ of steady rate pumping show the presence of aerobic 1981). The turbidity is normally residuals of drill cuttings and/or drilling fluids that have been pushed out into the formation surrounding the borehole during the well construction process. Turbidity levels for common water sources are given in Table 2.

The turbidity of well water is quite low, Sand content, turbidity, $\mathrm{pH}$, temperature and EC were measured during airlift discharge). The acceptance criteria were met for each discharge rate: i.e. Turbidity $<0.2$ NTU and sand content 0 ppm, after completing airlift pumping and backwashing, simultaneous swabbing/airlifting, until the acceptance criteria were met EC $<383 \mu \mathrm{S} / \mathrm{cm}$ and sand content $0 \mathrm{ppm}$. These results illustrated in Figure 2(a), Figure 2(b) the well was cleaned from the sterilization solution by airlifting until chlorine concentration in the water reached $0 \mathrm{mg} / \mathrm{l}(\mathrm{ppm})$. While the turbidity of dirty river and lake may be several orders of magnitude greater. As a result of population pressure, increased development, and decreasing costs of pumping water from wells, the aquifer resources are declining in many parts of the world.

It can be expected that future use of the more turbid surface water will increase relative to well water usage (Feachem, Mc Garry, and Mara, 1977) [20]. The turbidity levels cause filters to become clogged rapidly, thereby increasing the filter maintenance needs. Sedimentation basin allows much larger particles to settle to 25 micrometers, eliminating most of turbidity and also remove organic and ionic color. When treating surface water pretreatment to remove turbidity must be include in the cost of chemical, UV, and filtration system (Schulz, Okun, 1984; Cheremisin, 1995) [21] [22].

On site measurements it was obtained the following results after sterilization which illustrated in Table 3.

From Table 4 Water from a water supply system that has been treated with chlorine can be turbid due to the effect of the chlorine on minerals in the water, the analyses test for samples of water after disinfection and sterilization the wells show the Iron Bacteria were not seen and the Bacteria Species/Anaerobic Bacteria was absent. 
Table 2. On-site physicochemical parameters measurements during SRPT.

\begin{tabular}{ccc}
\hline Parameters & 1st sample & 2nd Sample \\
\hline Temperature $\left[{ }^{\circ} \mathrm{C}\right]$ & 30.0 & 30.3 \\
Electrical Conductivity $[\mu \mathrm{S} / \mathrm{cm}]$ & 370 & 339 \\
$\mathrm{PH}$ & 7.3 & 7.6 \\
$\mathrm{eH}[\mathrm{m} \mathrm{V}]$ & 90 & 120 \\
Turbidity $[\mathrm{NTU}]$ & 4.41 & 2.48 \\
$\mathrm{O}_{2}[\mathrm{mg} / \mathrm{l}]$ & 4.04 & 5.06 \\
$\mathrm{H}_{2} \mathrm{~S}[\mathrm{mg} / \mathrm{l}]$ & 0.26 & 0.13 \\
$\mathrm{CO}_{2}[\mathrm{mg} / \mathrm{l}]$ & 80 & 107 \\
\hline
\end{tabular}

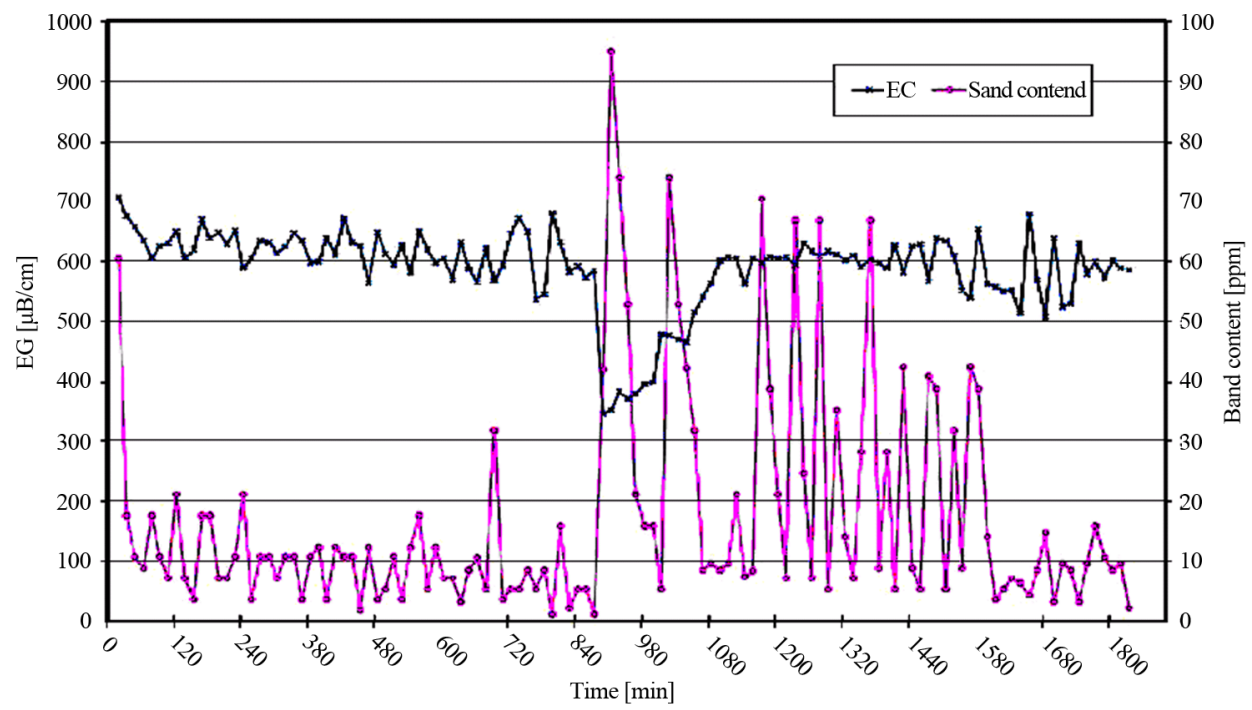

(a)

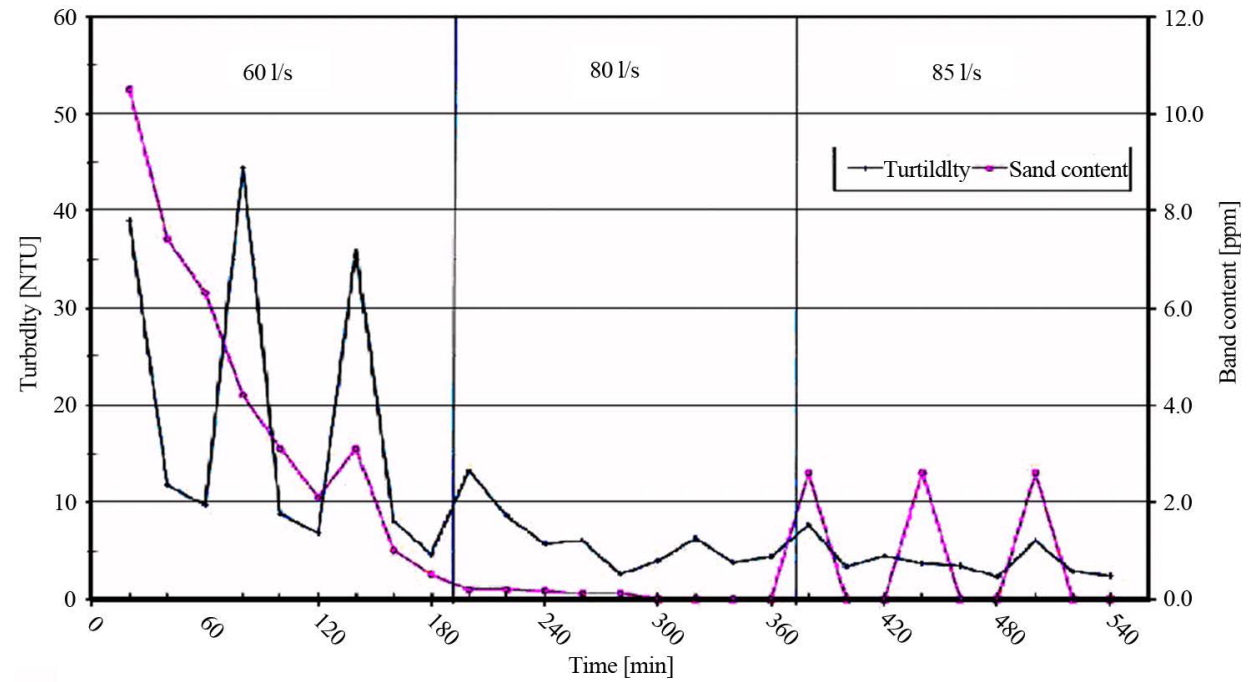

(b)

Figure 2. (a) Sand content and Electrical Conductivity measurements during Swabbing and Airlifting. (b) Sand content and turbidity measurements during High Rate Pumping and Backwashing. 
Table 3. On site measurements.

\begin{tabular}{cccccccc}
\hline Temperature ${ }^{\circ} \mathrm{C}$ & $\mathrm{Ec} \mu \mathrm{s} / \mathrm{cm}$ & $\mathrm{PH}$ & $\mathrm{eH}(\mathrm{mv})$ & $\mathrm{O}_{2} \mathrm{mg} / \mathrm{l}$ & Turbidity Ntu & $\mathrm{H}_{2} \mathrm{~S}$ & $\mathrm{CO}_{2}$ \\
\hline 29.6 & 289 & 7.79 & 43 & 7.25 & 0.21 & 0 & - \\
Odour & & $\mathrm{NO}$ & & color & & no & - \\
\hline
\end{tabular}

Table 4. Analysis test report for sample of water after disinfection and sterilization the well.

\begin{tabular}{cccc}
\hline Component & Result & Unit & LRV \\
\hline Electrical conductivity & 383 & $\mu \mathrm{s} / \mathrm{cm}$ & 2 \\
Total Dissolved Solids & 260 & $\mathrm{mg} / \mathrm{l}$ & 20 \\
Hardness & 130 & $\mathrm{mg} / \mathrm{l}$ & 1.70 \\
Alkalinity & 102.50 & $\mathrm{mg} / \mathrm{l}$ & 0.20 \\
Turbidity & 2.35 & $\mathrm{Ntu}$ & 0.30 \\
Calcium & 37.20 & $\mathrm{mg} / \mathrm{l}$ & 0.30 \\
Magnesium & 6.12 & $\mathrm{mg} / \mathrm{l}$ & 0.20 \\
Nitrate & 9.89 & $\mathrm{mg} / \mathrm{l}$ & 0.01 \\
Ammonium & 0.01 & $\mathrm{mg} / \mathrm{l}$ & 0.10 \\
Iron & 0.63 & $\mathrm{mg} / \mathrm{l}$ & - \\
PH & 7.66 & $\mathrm{unit}$ & - \\
Iron Bacteria & Were not seen & - & - \\
\hline
\end{tabular}

Extended pumping normally clears the water of turbidity, and shown the turbidity of well water after sterilization is quite low 0.21, and Hypochlorite acid (HOCL) will form in waters ranging from PH 6.5 - 7.79. As the PH increase above 7.5 affects disinfection speed with high temperature provide to fast disinfection. Nitrate concentrations above $10 \mathrm{mg} / \mathrm{l}$ can cause blood disorder in infants (blue baby disease). Elevated levels indicate that mature, sewage, or nitrogen fertilizers are reaching the source. If nitrate levels above $45 \mathrm{mg} / \mathrm{l},(10 \mathrm{mg} / \mathrm{l}$ nitrates as nitrogen) persist, the source of nitrate animal confinement areas, privies should be determined and relocated. The nitrate concentration is above $1 \mathrm{mg} / \mathrm{l}$ the water must not be given to infants and a different source (boiled for disinfection). Table 4 shows that the concentration of nitrate range between $9.6 \mathrm{mg} / \mathrm{l}$ (boiled for disinfection) must be used. Many naturally occurring minerals and chemicals such as Calcium, Potassium, Sodium or Fluoride are beneficial to human health. These will impart a taste to the water that may take some getting used to. The total dissolved solids range $260 \mathrm{mg} / \mathrm{l}$ and are typical of low mineralized groundwater from sandstone aquifer. These values which correspond to the electrical conductivity with values $383 \mu \mathrm{S} / \mathrm{cm}$ are low.

\section{Conclusion}

The total dissolved solids $320 \mathrm{mg} / \mathrm{l}$ are low and typical of low mineralized groundwater from sandstone aquifer. These values correspond to the electrical conductivity, with values between 370 and $339 \mu \mathrm{S} / \mathrm{cm}$. The threshold value for manganese $(0.1 \mathrm{mg} / \mathrm{l})$ is exceeded on both samples, with concentrations of 0.27 and $0.48 \mathrm{mg} / \mathrm{l}$ aerobic. The turbidity of well water is quite low, sand content, turbidity, $\mathrm{pH}$, temperature and EC were measured during airlift discharge. The acceptance criteria were met for each discharge rate: i.e. Turbidity $<0.2 \mathrm{NTU}$ and sand content $0 \mathrm{ppm}$. The analyses test for samples of water after disinfection and sterilization the wells showed the Iron Bacteria were not seen and the Bacteria Species/Anaerobic Bacteria was absent.

\section{References}

[1] Turneaure, F.E. and Russell, H.L. (1901) Public Water-Supplies Requirements, Resources, and the Concentration of Works. John Wiley \& Sons, Inc., New York, 493. 
[2] Whipple, G.C. (1906) Disinfection as a Means of Water Purification. Proceedings of American Water Works Association, 266-280.

[3] Baker, M.N. (1981) The Quest for Pure Water, the History of Water Purification from the Earliest Records to the Twentieth Century. 2nd Edition, Volume 1, American Water Works Association, Denver, 258-276.

[4] Leal, J.L (1909) The Sterilization Plant of the Jersey City Water Supply at Boonton, N.J. Proceedings of American Water works Association, 100-109.

[5] Hodges, L (1977). Environmental Pollution. 2nd Edition, Rinehart and Winston, New York, 189.

[6] Fair, G.M., Corris, J., Chang, S.L., Weil, I. and Burden, R.P. (1948) The Behavior of Chlorine as a Water Disinfectant. Journal of the American Water Works Association, 40, 1051-1061.

[7] Nakagawara, S., Goto, T., Nara, M., Ozawa, Y., Hotta, K. and Arata, Y. (1998) Spectroscopic Characterization and the PH Dependence of Bactericidal Activity of the Aqueous Chlorine Solutions. Analytical Sciences, 14, 691-698. http://dx.doi.org/10.2116/analsci.14.691

[8] Bouwer, H. (1984) Disinfection of Water Manual. Water Division Michigan Department of Environmental Quality, $1-51$.

[9] Roscoe Moss Company (1990) Handbook of Ground Development. John Wiley \& Sons. Inc.

[10] Driscoll, F.G. (1986) Ground Water and Wells. 2nd Edition, Johnson Division, St. Paul.

[11] Connell, G.F. (1996) The Chlorination/Chloramination Handbook. American Water Works Association Co., Denver.

[12] Holben, R.J. and Gaber, M. (2004) "Sanitary Drilling Practices: Ensure thorough Disinfection before the Well Even Is Built. National Driller.

[13] Hoben, R.J. and Gaber, M. (2003) Water Well Disinfection Manual. Water Division Michigan Department of Environmental Quality, Lansing.

[14] (2012) Disi-Mudawarra to Amman Water Conveyance System Project. Final Technical Report Well-39.

[15] Coombs, A.W. (2001) Baroid Industrial Drilling Products, Letter to Michigan Department of Environment Quality.

[16] Schnieders, J.H., (1998) Well Chlorination. Water Well Journal.

[17] Schnieders, J.H. (2001) Coliforms and Dinfection of Water Well. Water Well Journal, 55, 12, 14-15.

[18] Williams, R.B. and Culp, G.L. (1986) Handbook of Public Water System. Van Nostrand Reinhold, New York.

[19] LeChevallier, M.W., Evans, T.M. and Seidler, R.J. (1981) Effect of Turbidity on Chlorination Efficiency and Bacterial Persistence in Drinking Water. Applied and Environmental Microbiology, 42, 159-167.

[20] Feachem, R., McGarry, M. and Mara, D. (1977) Water, Wastes, and Health in Climates. John Wiley and Sons, Chichester.

[21] Schulz, C.R. and Okun, D.A. (1984) Surface Water Treatment for Communities in Developing Countries. John Wiley and Sons, NewYork.

[22] Cheremisinoff, P. (1995) Handbook of Water and Wastewater Treatment Technology. Marcel Dekker, New York. 